\title{
Pengaturan Mengenai Pendaftaran Pendirian Firma Pada Sistem Administrasi Badan Usaha
}

\author{
I Made Hengki Permadi ${ }^{1}$ \\ 1Program Magister (S2) Kenotariatan Fakultas Hukum Universitas Udayana, \\ E-mail: hengkypermadi94@gmail.com
}

\begin{tabular}{l}
\hline Info Artikel \\
\hline Masuk : 22 Juni 2019 \\
Diterima : 21 Juli 2019 \\
Terbit : 30 Desember 2019 \\
Keywords: \\
Registration; Firm; \\
Administration System. \\
\\
\\
Kata kunci: \\
Pendaftaran; Firma; Sistem \\
Administrasi. \\
Corresponding Author: \\
I Made Hengki Permadi, E-mail: \\
hengkypermadi94@gmail.co \\
\hline
\end{tabular}

\begin{abstract}
The process or procedure for establishing a firm is regulated in Article 22 and Article 23 of the Commercial Law Code (hereinafter referred to as KUHD). In this provision, it is stipulated that the firm must be established with an authentic deed and registered with the Registrar of the District Court where the firm was established. The regulations in the KUHD are not in line with the Minister of Law and Human Rights Regulation Number 17 Year 2018 regarding the Registration of the Military Alliance, the Fima Alliance and the Civil Alliance which indicates that the registration of the firm is carried out in the Legal Entity Administration System (hereinafter referred to as $S A B U$ ). it appears that there is a norm conflict between the two rules. This study aims to determine the arrangements in registering the Firm and the legal consequences of not registering the Firm in the Business Entity Administration System $(S A B U)$. This research is a normative legal research. In research using a statutory and conceptual approach. Using primary and secondary legal materials. The results showed that based on the principle of Lex Superiori derogate Legi Inferiori, based on the hierarchy of statutory regulations, the KUHD which is equivalent to the Law is stronger than the Regulation of the Minister of Law and Human Rights Number 17 of 2018 concerning Registration of Komanditer Alliance, Firm Alliance and Civil Alliance whose position is under Government Regulations and Presidential Regulations, because the Acts are higher than Government Regulations and Presidential Regulations. The legal consequence of not registering a firm with $S A B U$ is that the name of the firm can be used first by other firms so it must change the name of the firm concerned with another name because in the $S A B U$ system there is a registration of the firm's alliance name. If there is a partnership with another firm that registers the name of the firm first, then the name of the same firm cannot be registered again and the firm is deemed invalid.
\end{abstract}

\begin{tabular}{l} 
Abstrak \\
\hline Proses atau tata cara pendirian firma diatur dalam Pasal 22 dan \\
Pasal 23 Kitab Undang-Undang Hukum Dagang (yang \\
selanjutnya disebut KUHD). Dalam ketentuan tersebuti \\
menentukan bahwa firma harus didirikan dengan akta otentik dan \\
didaftarkan pada Kepaniteraan Pengadilan Negeri dimana firma \\
tersebut didirikan. Peraturan dalam KUHD tersebut tidak sejalan \\
dengan Peraturan Menteri Hukum dan Hak Asasi Manusia \\
Nomor 17 Tahun 2018 tentang Pendaftaran Persekutuan \\
Komanditer, Persekutuan Fima dan Persekutuan Perdata yang \\
mengisyaratkan bahwa pendaftaran firma dilakukan pada Sistem \\
Administrasi Badan Hukum (yang selanjutnya disebut SABU).
\end{tabular}




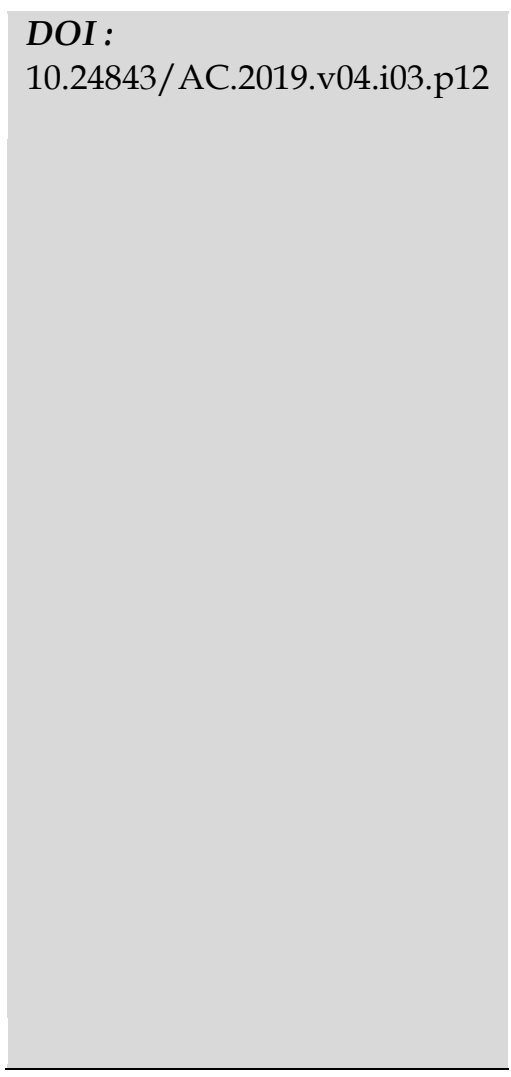

terlihat bahwa adanya konflik norma diantara kedua aturan itu. Penelitian ini bertujuan untuk mengetahui pengaturan dalam pendaftaran Firma dan akibat hukum apabila tidak mendaftarkan Firma pada Sistem Administrasi Badan Usaha (SABU). Penelitian ini merupakan penelitian hukum normatif. Dalam penelitian menggunakan pendekatan perundang-undangan dan konseptual. Menggunakan bahan hukum primer dan sekunder. Hasil penelitian menunjukkan bahwa berdasarkan asas Lex Superiori derogate Legi Inferiori maka berdasarkan hirarki peraturan perundang-undangan, KUHD yang setara dengan UndangUndang lebih kuat dibanding Peraturan Menteri Hukum dan Hak Asasi Manusia Nomor 17 Tahun 2018 tentang Pendaftaran Persekutuan Komanditer, Persekutuan Firma dan Persekutuan Perdata yang kedudukannya dibawah Peraturan Pemerintah dan Peraturan Presiden, karena Undang-Undang kedudukannya lebih tinggi dari Peraturan Pemerintah dan Peraturan Presiden. Akibat hukum dari tidak didaftarkannya firma pada $S A B U$, yaitu nama firma dapat dipakai terlebih dahulu oleh firma lainnya sehingga harus mengganti nama firma yang bersangkutan dengan nama yang lain karena di dalam sistem SABU terdapat pendaftaran nama persekutuan firma. Jika ada persekutuan firma lain yang mendaftarkan nama firmanya terlebih dahulu maka nama firma yang sama tidak akan bisa didaftarkan kembali dan firma tersebut dianggap tidak sah pendiriannya.

\section{Pendahuluan}

Firma dapat dikatakan persekutuan (maatschap) adalah orang-orang yang melakukan kerja secara bersama-sama yang biasanya rekan sejawat dapat pula rekan seprofesi ataupun teman dalam hal berdagang. ${ }^{1}$ Maka dari itu masing-masing personal memiliki peran yang sangat penting, namun menonjolkan persatuan kerja sama antar rekan dalam satu firma. Firma dapat dikatakan bahwa perusahaan yang bernaung dalam satu nama bersama. ${ }^{2}$ Firma adalah permitraan biasanya bergerak dalam bidang profitable atau yang mengutungkan. Landasan hukum firma dapat dilihat pada Kitab Undang-Undang Hukum Dagang (KUHD), yang diatur pada Pasal 16 hingga Pasal 35 KUHD. Adapun pengertian firma, yakni: setiap usaha atau perusahaan yang pendiriannya dalam rangka menjalankan usaha secara bersama-sama dengan menggunakan nama bersama atau di bawah nama bersama. ${ }^{3}$ Mengenai sumber hukum firma selain dapat ditemukan di dalam KUHD, dapat pula ditemukan dalam Kitab Undang-Undang Hukum Perdata (KUHPer) yakni pada Pasal 1618-1652 KUHPer. Mengenai pemberlakuan ketentuan KUHPer sebagai sumber hukum firma ditekankan pada Pasal 15 KUHD berbunyi sebagai berikut : Persekutuan-persekutuan yang termasuk dalam pada title ini diatur dalam perjanjian para pihak oleh kitab undang-undang ini serta oleh hukum perdata. Sehingga dapat diketahui bahwa selain KUHD sebagai sumber hukum bagi firma, terdapat pula KUHPer. KUHPer berlaku lex generalis atau sebagai aturan yang umum, sedangkan KUHD berlaku lex specialis atau aturan yang khusus.

\footnotetext{
${ }^{1}$ Harahap, M. Y. (2011). Hukum Perseroan Terbatas, Jakarta. Sinar Grafika, h. 8.

${ }^{2}$ Ibid, h. 8-9.

${ }^{3}$ Wijaya, I. G. R. (2006). Hukum Perusahaan: Undang-undang dan Peraturan Pelaksanaan di Bidang Usaha, Jakarta. Kesaint Blanc, h. 45.
} 
Pengaturan pendirian firma terdapat dalam Pasal 22 dan 23 KUHD. Pasal 22, yaitu : "Perseroan firma wajib didirikan dengan akta otentik". Pasal 23, yaitu : "Para persero firma wajib melakukan pendaftaran pada register kepaniteraan pengadilan negeri dimana firma tersebut berdiri". Dengan demikian, firma didirikan dengan pembuatan anggaran dasar yang dituangkan dalam akta pendirian yang dibuat oleh atau dihadapan notaris. Kemudian akta didaftarkan pada Kepaniteraan Pengadilan Negeri sesuai dengan domisili atau tempat kedudukan firma tersebut. Akta yang sudah dilakukan pendaftaran lalu diumumkan pada Berita Negara. Artinya bahwa berdasarkan Pasal 23 tersebut mewajibkan untuk mendaftarkan akta pendirian firma pada Kepaniteraan Pengadilan Negeri setempat, namun semenjak diundangkannya Peraturan Menteri Hukum dan Hak Asasi Manusia Republik Indonesia Nomor 17 Tahun 2018 tentang Pendaftaran Persekutuan Komanditer, Persekutuan Firma dan Persekutuan Perdata (yang selanjutnya disebut Permenkumham PPKPFPP), firma wajib didaftarkan kepada Menteri Hukum dan Hak Asasi Manusia melalui sistem elektronik bernama Sistem Administrasi Badan Usaha yang selanjutnya disebut SABU. Sistem SABU ini berada langsung dibawan naungan Kementerian Hukum dan Hak Asasi Manusia Direktorat Jenderal Administrasi Hukum Umum (AHU), dalam aturan itu disebutkan bahwa pendirian, perubahan maupun pembubaran firma wajib didaftarkan secara elektronik. Berdasarkan aturan pendaftaran firma yang dilihat dari KUHD dan Permenkumham PPKPFPP di atas maka terjadi konflik norma antara kedua aturan tersebut sehingga menimbulkan kebingungan bagi pendiri firma dalam mendaftarkan persekutuan firmanya agar firma tesebut dapat dikatakan sah berdiri. Berdasarkan latar belakang di atas maka penulis tertarik untuk mengangkat judul "Pengaturan Mengenai Pendaftaran Pendirian Firma Pada Sistem Administrasi Badan Usaha". Dari pemaparan di atas dapat ditarik 2 (dua) permasalahan mengenai pendaftaran Firma, yaitu Bagaimana pengaturan mengenai pendaftaran Firma? dan Bagaimana akibat hukum Firma yang tidak didaftarkan pada Sistem Administrasi Badan Usaha?

Penulisan ini bertujuan untuk mengetahui pengaturan dalam pendaftaran Firma dan untuk mengetahui akibat hukum apabila tidak mendaftarkan Firma pad Sistem Administrasi Badan Usaha (SABU). Melihat belum adanya artikel serupa yang membahas mengenai pendaftaran Firma pada SABU hal tersebut dapat menambah informasi dan pengetahuan dibidang kenotariatan khususnya terkait pendaftaran Firma serta secara khusus diharapkan bisa menjadi pedoman bagi notaris serta masyarakat yang ingin mendirikan Firma.

\section{Metode Penelitian}

Penelitian ini merupakan penelitian hukum normatif yang fokus dalam melakukan kajian terhadap norma-norma hukum. ${ }^{4}$ Adapun penelitian ini menekankan permasalahan yaitu terdapat konflik norma sehubungan dengan pendaftaran firma. Pada penelitian ini digunakan pendekatan perundang-undangan dan pendekatan konseptual. ${ }^{5}$ Penelitian ini menggunakan 2 (dua) sumber bahan hukum, yaitu bahan

\footnotetext{
${ }^{4}$ Winarta, E. N., Wairocana, I. G. N., \& Sarjana, I. M. Hak Pakai Atas Rumah Hunian Warga Negara Asing Dalam Perkawinan Campuran Tanpa Perjanjian Kawin. Acta Comitas, 43-57, h. 44.

${ }^{5}$ Diana, P. V. P., Mertha, I. K., \& Artha, I. G. (2015). Pertanggung Jawaban Notaris Dalam Pembuatan Akta Berdasarkan Pemalsuan Surat Oleh Para Pihak. Acta Comitas, 161-172, h. 164-165.
} 
hukum primer dan bahan hukum sekunder. ${ }^{6}$ Teknik pengumpulan bahan hukum primer dan bahan hukum sekunder adalah dengan teknik library research yaitu bahan hukum dikumpulkan melalui cara atau teknik dokumentasi, mengumpulkan dan membaca aturan-aturan yang berkaitan, studi pustaka melalui telaah literatur, artikel, maupun karya tulis. ${ }^{7}$ Dalam mengolah bahan hukum yang telah terkumpul baik yang didapat dari aturan-aturan terkait maupun buku-buku yang telah dibaca dilakukan dengan teknik analisis, yaitu teknik evaluasi dan teknik argumentasi. ${ }^{8}$

\section{Hasil dan Pembahasan}

Firma adalah salah satu bentuk usaha yang anggotanya terdiri dari 2 (dua) orang atau lebih melakukan suatu kesepakatan untuk melaksanakan pekerjaan secara bersamasama atau kerja sama untuk mencapai keuntungan bersama yang mana anggotaanggotanya tidak terbatas tanggung jawabnya terhadap terhadap perikatan Firma dengan pihak ketiga. ${ }^{9}$ Untuk mendirikan firma dilakukan melalui persetujuan yang dilakukan pihak-pihak yang terkait lalu persetujuan tersebut dibuatkan akta notariil, itu berarti bahwa pendirian firma berdasarkan akta yang dibuat dihadapan pejabat umum yang berwenang, yang dalam hal ini adalah notaris, lalu disahkan Kepaniteraan Pengadilan Negeri setempat. Jika dibandingkan dengan perusahaan perorangan seperti Usaha Dagang (UD) mendirikan firma dapat dikatakan lebih sulit karena memerlukan lebih dari satu orang anggota. Masing-masing anggota firma diwajibkan untuk menyetor harta kekayaannya baik itu sebagian maupun seluruhnya ke perusahaan serta di dalam akta wajib dicantumkan mengenai hal tersebut. Keuntungan yang didapat oleh firma akan dilakukan pembagian sesuai dengan kesepakatan sekutu atau anggota firma dan apabila firma merugi atau terjadi kerugian karena suatu hal maka sekutu firma memiliki tanggung jawab secara tanggung menanggung atau tanggung renteng mencakup harta pribadi masing-masing sekutu. Seluruh sekutu firma lebih cenderung memiliki sifat kekeluargaan dikarenakan hubungan antar sekutu biasanya anggota keluarga maupun teman seperjuangan atau teman dekat yang bersepakat untuk melakukan kerja sama dalam menjalankan suatu usaha untuk mencapai tujuan yaitu keuntungan dan memiliki tanggung jawab yang sama antar sekutu tetapi memiliki tugas yang berbeda sesuai keahlian masingmasing. ${ }^{10}$

Persekutuan firma merupakan persekutuan perdata yang dilaksanakan dengan menggunakan nama bersama. Persekutuan perdata merupakan perjanjian untuk menjalankan suatu usaha yang dilakukan 2 (dua) orang atau lebih bersepakat memberikan suatu hal kepada persekutuan yang bertujuan untuk mendapatkan

\footnotetext{
${ }^{6}$ Cahyani, I. A. M. D. S., Usfunan, Y., \& Sumardika, I. N. Kepastian Hukum Penyerahan Protokol Notaris Kepada Penerima Protokol. Acta Comitas, 137-150, h.140-141.

7 Diatmika, I. G. A. O., Atmadja, I. D. G., \& Utari, N. K. S. (2014). Perlindungan Hukum Terhadap Jabatan Notaris Berkaitan Dengan Adanya Dugaan Malpraktek Dalam Proses Pembuatan Akta Otentik. Acta Comitas, 150-160, h. 154.

${ }^{8}$ Prasminda, G. D., Usfunan, Y., \& Udiana, I. M. (2017). Kuasa Menjual Notariil Sebagai Instrumen Pemenuhan Kewajiban Debitur Yang Wanprestasi Dalam Perjanjian Utang Piutang. Acta Comitas, $57-$ 65 , h. 59.

${ }^{9}$ Mulhadi. (2017). Hukum Perusahaan (Bentuk-Bentuk Badan Usaha di Indonesia). PT RajaGrafindo Persada, h. 56.

${ }^{10}$ Muhammad, A. (2010). Hukum Perusahaan Indonesia. Bandung . Citra Aditya Bakti, h. 89.
} 
keuntungan (Pasal 1618 KUHPer). Berdasarkan pengertian di atas maka persekutuan itu baru dapat disebut firma bila memenuhi syarat-syarat, yaitu :

a. Persekutuan perdata ;

b. Melaksanakan suatu usaha ;

c. Memakai nama bersama ;

d. Para sekutu bertanggung jawab tanggung renteng sampai dengan harta kekayaan pribadi secara keseluruhan.

Firma memiliki arti nama bersama. Cara menuangkan nama bersama yang dipakai untuk perusahaan, yaitu :

a. Penggunaan nama salah satu sekutu, seperti Budi Jaya;

b. Penggunaan nama salah satu anggota yang diikuti tambahan bahwa terdapat anggota keluarga, seperti Fa Adian Steve and Bros;

c. Penggunaan nama yang menyesuaikan dengan usaha yang dijalankan atau bidang usaha, seperti Fa Sapi Perah;

d. Penggunaan gabungan inisial para anggota, seperti Fa Baru (singkatan dari Budi, Arya, Rani, dan Ulfa);

e. Penggunaan nama yang lainnya , seperti Fa Bhineka Jaya Mandiri. ${ }^{11}$

Pasal 16 KUHD mengatur bahwa Persekutuan Firma adalah usaha yang dilakukan 2 (dua) orang sekutu atau lebih memiliki tujuan untuk mencari keuntungan di bawah nama bersama. Aturan yang mengatur mengenai persekutuan firma dapat dilihat pada Pasal 16 hingga 35 KUHD serta diatur pula dalam KUHPer. Pada Pasal 22 KUHD mengatur agar tidak terdapat penyangkalan terhadap pihak ketiga, pendirian persekutuan firma diharuskan menggunakan akta otentik. Selanjutnya Pasal 23 dan Pasal 28 KUHD berbunyi, pendaftaran pada Kepaniteraan Pengadilan Negeri sesuai tempat kedudukan persekutuan firma dilakukan setelah dibuatkannya akta pendirian persekutuan firma, lalu akta pendirian tersebut diterbitkan atau diumumkan pada Berita Negra Republik Indonesia (BNRI). Firma dapat dianggap sebagai perusahaan yang umum oleh pihak ketiga yang bidang usahanya tidak tertentu, untuk jangka waktu yang tidak ada batasnya, serta para sekutu memiliki wewenang yang sama untuk menandatangani segala surat serta mewakili perusahaan bila akta pendirian belum dilakukan pendaftaran pada Pengadilan Negeri serta belum dilakukan pengumuman pada BNRI sesuai dengan bunyi Pasal 29 KUHD. Di dalam akta tersendiri harus menentukan atau menunjuk sekutu yang diberikan kuasa untuk melakukan kepengurusan perusahaan. pentingnya hal tersebut dilakukan agar pihak ketiga tahu siapa yang ditunjuk sebagai pengurus sehingga menjadi lebih jelas apabila ingin berhubungan dengan pengurus. Pada klausul yang menentukan mengenai pengurus harus diatur pula mengenai hak pengurus mewakili persekutuan firma sesuai dalam Pasal 17 KUHD. Apabila tidak ditentukan maka para sekutu dapat menjadi perwakilan bagi firma selama melakukan perbuatan untuk urusan atau kepentingan firma (Pasal 18 KUHD). Walaupun ada penunjukan seorang pengurus namun tetap saja semua sekutu firma memiliki kekuasaan tertinggi yang sama

${ }^{11}$ Ibid, h. 88 . 
kedudukannya jadi segala urusan firma harus diputuskan berdasarkan musyawarah terlebih dahulu sesuai dengan anggaran dasar firma.

Pasca dikeluarkannya Permenkumham PPKPFPP, sesuai dengan Pasal 3 Permenkumham PPKPFPP, permohonan pendaftaran firma harus mengajukan permohonan kepada Menteri dengan menggunakan media elektronik, yaitu Sistem Administrasi Badan Usaha (SABU) pada website Direktorat Jenderal Administrasi Hukum Umum (AHU) Kementerian Hukum dan Hak Asasi Manusia. Sebenarnya pelaksanaan pendaftaran firma secara elektronik tersebut diadopsi dari pendaftaran elektronik badan hukum yang telah terlebih dahulu dilaksanakan dan berlaku hingga saat ini. Pada SABU terdapat 3 (tiga) opsi pendaftaran untuk persekutuan firma, yaitu mengenai pendaftaran akta pendirian, pendaftaran perubahan anggaran dasar, serta pendaftaran perubahan (Pasal 2 Permenkumham PPKPFPP).

Berlakunya Permenkumham PPKPFPP mengakibatkan sistem pendaftaran firma menjadi sama dengan pendaftaran badan hukum. Lahirnya Permenkumham PPKPFPP ini bermanfaat karena tidak akan ditemukan badan usaha yang memiliki nama yang sama apabila telah terdaftar pada SABU. Selain itu sistem ini dapat menurunkan pungutan liar (pungli) karena segala urusan dilangsungkan pada media elektronik yang tidak perlu berurusan dengan orang secara langsung. Berangkat dari Permenkumham PPKPFPP, dapat membantu seluruh Badan Usaha, baik itu CV, Firma atau Persekutuan Perdata untuk pencatatan dan pendaftaran melalui notaris. atas kedua aturan mengenai pendaftaran firma tersebut diatas apakah pendiri firma akan mengikuti KUHD atau Permenkumham PPKPFPP untuk mendaftarkan pendirian firmanya.

Dilihat dari kedudukannya, awal mula dan sumber terpenting dari hukum dagang adalah KUHPer yang dapat ditemukan dalam Pasal 1 KUHD, KUHD adalah hukum perdata khusus maka dapat diberlakukan asas lex specialis derogate legi generalis ${ }^{12}$, yang konsekuensinya adalah bila di dalam KUHD tidak terdapat aturan suatu hal mengenai firma maka KUHPer dapat berlaku, namun jika keduanya mengatur maka yang dipakai peraturan yang lebih khusus yaitu KUHD. Di tahun 1945 sesudah kemerdekaan Indonesia, KUHD dan KUHPer masih tetap diberlakukan di Indonesia. Dilihat dari Pasal II aturan peralihan Undang-Undang Dasar 1945, disebutkan bahwa : seluruh badan Negara beserta aturan-aturan yang ada masih berlaku, selama belum adanya pembaharuan berdasarkan Undang-Undang Dasar ini. Jika dilihat bunyi pasal tersebut maka KUHD dan KUHPer masih diberlakukan sebagai peraturan perundangundangan selama belum terdapat suatu aturan baru yang menggantikan.

Melihat pemaparan di atas maka dikatakan KUHD dan KUHPer merupakan undangundang yang dikitabkan sehingga disebut kitab undang-undang. KUHD dan KUHPer sampai sekarang masih tetap berlaku di Indonesia. Jika dilihat berdasarkan Pasal 7 ayat (1) Undang-Undang Nomor 12 Tahun 2011 tentang Pembentukan Peraturan Perundang-Undangan (yang selanjutnya disebut UU 12/2011), menentukan hierarki peraturan perundang-undangan, yaitu :

a. Undang-Undang Dasar Negara Republik Indonesia Tahun 1945 ;

b. Ketetapan Majelis Permusyawaratan Rakyat ;

\footnotetext{
${ }^{12}$ Dharnayanti, N. M. P., Usfunan, Y., \& Sarjana, I. M. (2017). Hubungan Hukum Perusahaan Induk Berbentuk Perseroan Terbatas Dengan Anak Perusahaan Berbentuk Persekutuan Komanditer. Acta Comitas, 66-74. h. 68.
} 
c. Undang-Undang/Peraturan Pemerintah Pengganti Undang-Undang ;

d. Peraturan Pemerintah ;

e. Peraturan Presiden ;

f. Peraturan Daerah Provinsi ; dan

g. Peraturan Daerah Kabupaten/Kota.

Pengaturan di atas jika dilihat dan dihubungkan dengan kedudukan KUHD tidak terdapat suatu masalah karena KUHD masih diberlakukan sebagai undang-undang hingga saat ini. Maka sesuai dengan aturan diatas kedudukan KUHD setara dengan Undang-Undang berada di antara Ketetapan MPR dan Peraturan Pemerintah. Sedangkan kedudukan Permenkumham PPKPFPP berdasarkan Pasal 8 ayat (1) UU 12/2011 disebutkan bahwa peraturan lain selain yang tercantum dalam pasal 7 ayat (1) mencakup pula peraturan yang ditetapkan oleh Lembaga Negara termasuk pula Menteri. Dilihat dari pasal di atas maka peraturan menteri diakui pula sebagai aturan serta dapat dimasukan dalam hierarki peraturran perundang-undangan, namun kedudukannya masih di pertanyakan termasuk kedalam yang mana jika dilihat berdasarkan Pasal 7 ayat (1) UU 12/2011. Definisi menteri jika dilihat pada Pasal 1 angka 12 PPKPFPP, bahwa "Menteri adalah menteri yang menyelenggarakan urusan pemerintahan pada bidang hukum dan HAM “. Melihat Pasal 1 angka 2 UndangUndang Republik Indonesia Nomor 39 Tahun 2008 Tentang Kementerian Negara mengatur "Menteri Negara yang selanjutnya disebut Menteri adalah pembantu Presiden yang memimpin Kementerian". Jadi kedudukan Permenkumham PPKPFPP berada dibawah Peraturan Pemerintah dan Peraturan Presiden karena Menteri Hukum dan HAM memiliki kedudukan sebagai pembantu presiden yang artinya kedudukannya berada di bawah presiden. Dari kedua aturan tersebut jika dilihat berdasarkan asas preferensi yaitu asas Lex Superior Derogate Legi Inferiori yaitu undangundang yang tingkatannya lebih tinggi mengesampingkan undang-undang yang tingkatannya lebih rendah, jadi aturan yang dipakai dasar untuk mendaftarkan firma adalah KUHD karena KUHD setara dengan Undang-Undang sedangkan Permenkumham PPKPFPP kedudukannya di bawah Peraturan Pemerintah dan Peraturan Presiden yang kedudukannya lebih rendah dari Undang-Undang.

\subsection{Akibat Hukum Firma yang tidak Didaftarkan Pada Sistem Administrasi Badan Hukum (SABU)}

Pendaftaran firma pada SABU meliputi pendaftaran pendirian, perubahan serta pembubaran. Mekanisme permohonan pendaftaran firma pada SABU di awali dengan permohonan pengajuan nama. Hal tersebut bisa ditemukan dalam Pasal 5 ayat (1) Permenkumham PPKPFPP mengatur bahwa pemohon mendaftarkan permohonan ajuan nama CV, Firma dan PP terhadap menteri pada SABU. Dalam Ayat (2) menyebutkan bahwa Nama CV, Firma dan PP berdasarkan ayat (1) tersebut wajib memenuhi syarat-syarat:
a. Penulisan menggunakan huruf latin ;
b. Belum pernah digunakan oleh CV, Firma dan PP yang telah terdaftar pada SABU ;
c. Tidak berlawanan dengan ketertiban umum dan kesusilaan ; 
d. Dilarang menggunakan nama yang sama ataupun mirip dengan Lembaga Negara, Pemerintah maupun internasional kecuali telah mendapatkan izin oleh lembaga yang bersangkutan; dan

e. bukan tersusun berdasarkanangka/serangkaian angka, huruf/serangkaian huruf yang tidak membentuk suatu kata.

Berdasarkan Pasal 5 tersebut maka firma diwajibkan untuk mengajukan permohonannya kepada Menteri pada SABU agar nama firma sebagai identitas perusahaan tidak sama dengan firma yang lainnya. Mengenai akibat hukum tidak mendaftarkan firma pada SABU, jika dilihat pada Pasal 5 ayat (2) huruf b, pada huruf $\mathrm{b}$ tersebut tercermin apabila tidak segera mendaftarkan firma pada SABU maka nama firma dapat dipakai terlebih dahulu oleh firma lainnya sehingga tidak dapat memakai nama firma yang telah digunakan, jadi mau tidak mau harus mengganti nama firma dengan nama lain yang berbeda dengan nama firma-firma yang telah terdaftar pada SABU.

Selain itu pada Pasal 14 ayat (1) Permenkumham PPKPFPP mengatur bahwa menteri menerbitkan surat keterangan terdaftar apabila permohonan pendaftaran Firma telah diterima. Surat keterangan terdaftar itu merupakan bukti bahwa firma tersebut memang telah sah berdiri dan memenuhi asas hukum perusahaan yaitu asas publisitas agar publik dapat dengan mudah mengakses serta mengetahui lokasi dimana perusahaan tersebut sehingga dapat mendukung patuhnya kewajiban para pendiri perusahaan kepada masyarakat atau pihak ketiga yang berhubungan dengan perusahaan tersebut, jadi akibat hukum lainnya apabila pendirian firma tidak didaftarkan pada SABU maka firma tersebut dinyatakan tidak secara sah berdiri dan tidak memenuhi asas publisitas yang artinya bahwa firma dapat dikatakan sebagai perusahaan umum yang menjalankan usahanya secara umum dan jangka waktunya tidak terbatas serta anggaran dasarnya menjadi tidak mengikat para sekutu yang artinya bahwa bidang usaha yang dijalankan oleh firma tersebut tidak ditentukan secara spesifik dan yang berwenang mewakiliki firma tidak ditentukan secara khusus jadi tiap sekutu berhak mewakili firma dan apabila salah satu sekutu melakukan perikatan dengan pihak ketiga yang bertentangan dengan anggaran dasar maka tanggung jawabnya tetap dilakukan secara tanggung renteng oleh para sektu, tidak hanya menjadi tanggung jawab individu yang melakukan kesalahan yang bertentangan dengan anggaran dasar tersebut.

Sebenarnya jika dilihat-lihat pada Pasal 5 dan Pasal 14 ayat (1) Permenkumham PPKPFPP tidak tersurat secara jelas mengenai apa akibat hukum jika para pendiri firma tidak mendaftarkan firma pada SABU, maka sebaiknya pengaturan mengenai sanksi dibuat secara khusus apabila para pendiri firma tidak mendaftarkan firmanya pada SABU agar akibat hukum dari tidak didaftarkannya firma pada SABU menjadi lebih jelas dan tegas. Sehingga memacu bagi para pendiri firma untuk melaksanakan kewajibannya untuk melakukan pendaftaran firma pada SABU dan tidak terjadi permasalahan terhadap firma terkait kesamaan nama antara satu firma dengan firma yang lainnya yang dapat merugikan perusahaan karena tidak ada pembeda apabila ada kesamaan nama yang menyebabkan klien kebingungan untuk membedakan firmafirma yang memiliki kesamaan nama tersebut. Serta terkait legalitas berdirinya firma atau sah tidaknya firma berdiri yang apabila tidak memiliki surat keterangan terdaftar sesuai pasal 14 ayat (1) maka firma tersebut dapat dianggap perusahaan yang umum yang para perseronya memiliki tanggung jawab yang sama secara tanggung renteng 
sampai dengan harta kekayaan pribadinya terhadap pihak ketiga dan setiap persero dapat mewakili firma untuk melakukan penandatanganan. Menurut penulis hal tersebut sama dengan konsekuensi yang diatur dalam Pasal 29 KUHD mengenai tidak mendaftarkan dan mengumumkan firma pada kepaniteraan pengadilan negeri.

\section{Kesimpulan}

Hingga saat ini KUHD masih berlaku sebagai Undang-Undang sedangkan kedudukan Permenkumham PPKPFPP berada di bawah Peraturan Pemerintah dan Peraturan Presiden sehingga berdasarkan asas Lex Superiori derogate Legi Inferiori maka kedudukan KUHD lebih tinggi dibanding Permenkumham PPKPFPP.

Sebenarnya akibat hukum tidak didaftarkannya firma pada SABU tidak tersurat namun berdasarkan Pasal 5 permenkumham PPKPFPP firma diwajibkan untuk mengajukan permohonan nama pada SABU agar nama firma sebagai identitas perusahaan tidak sama dengan firma yang lainnya. Maka akibat hukum dari tidak didaftarkannya firma pada SABU, nama firma dapat dipakai terlebih dahulu oleh firma lainnya sehingga harus mengganti nama firma yang bersangkutan dengan nama yang lain dan firma dianggap tidak sah berdiri serta dianggap menjadi perusahaan yang umum yang tanggung jawab sekutunya sama, serta para sekutu berhak mewakili perusahaan walaupun di dalam anggaran dasar terdapat sekutu yang tidak berhak mewakili.

\section{Daftar Pustaka}

\section{Buku}

Harahap, M. Y. (2011). Hukum Perseroan Terbatas, Jakarta. Sinar Grafika.

Muhammad, A. (2010). Hukum Perusahaan Indonesia. Bandung. Citra Aditya Bakti.

Mulhadi. (2017). Hukum Perusahaan (Bentuk-Bentuk Badan Usaha di Indonesia). PT RajaGrafindo Persada.

Wijaya, I. G. R. (2006). Hukum Perusahaan: Undang-undang dan Peraturan Pelaksanaan di Bidang Usaha, Jakarta. Kesaint Blanc.

\section{Jurnal}

Cahyani, I. A. M. D. S., Usfunan, Y., \& Sumardika, I. N. Kepastian Hukum Penyerahan Protokol Notaris Kepada Penerima Protokol. Acta Comitas, 137-150.

Dharnayanti, N. M. P., Usfunan, Y., \& Sarjana, I. M. (2017). Hubungan Hukum Perusahaan Induk Berbentuk Perseroan Terbatas Dengan Anak Perusahaan Berbentuk Persekutuan Komanditer. Acta Comitas, 66-74.

Diana, P. V. P., Mertha, I. K., \& Artha, I. G. (2015). Pertanggung Jawaban Notaris Dalam Pembuatan Akta Berdasarkan Pemalsuan Surat Oleh Para Pihak. Acta Comitas, 161-172.

Diatmika, I. G. A. O., Atmadja, I. D. G., \& Utari, N. K. S. (2014). Perlindungan Hukum Terhadap Jabatan Notaris Berkaitan Dengan Adanya Dugaan 
Malpraktek Dalam Proses Pembuatan Akta Otentik. Acta Comitas, 150160.

Prasminda, G. D., Usfunan, Y., \& Udiana, I. M. (2017). Kuasa Menjual Notariil Sebagai Instrumen Pemenuhan Kewajiban Debitur Yang Wanprestasi Dalam Perjanjian Utang Piutang. Acta Comitas, 57-65.

Winarta, E. N., Wairocana, I. G. N., \& Sarjana, I. M. Hak Pakai Atas Rumah Hunian Warga Negara Asing Dalam Perkawinan Campuran Tanpa Perjanjian Kawin. Acta Comitas, 43-57.

\section{Peraturan Perundang-Undangan}

Undang-Undang Dasar Negara Republik Indonesia Tahun 1945.

Kitab Undang-undang Hukum Perdata terjemahan R. Subekti, Penerbit Balai Pustaka, Jakarta, 2009.

Kitab Undang-Undang Hukum Dagang.

Peraturan Menteri Hukum dan Hak Asasi Manusia Republik Indonesia Nomor 17 Tahun 2018 tentang Pendaftaran Persekutuan Komanditer, Persekutuan Firma, dan Persekutuan Perdata. 